\title{
Possible alternatives in crop nutrition
}

\author{
Brigitta Tóth \\ University of Debrecen, Institute of Crop Sciences, Department of Agricultural Botany and Crop Physiology, \\ 4032 Debrecen, Böszörményi str. 138. Hungary, \\ btoth@agr.unideb.hu
}

Keywords: crop nutrition, lime sludge, sewage sludge

SUMMARY

The protection of the environment is our common task. All pollution that exposes our soils, plants or the environment - as taken in any proper or extended sense - will appear sooner or later in the food chain and in human beings who are on the top of the food-chain pyramid. The aim of our work is to give a brief overview of the effects of selected industrial wastes on the physiological parameters of corn plants. Sewage sludge and lime sludge were examined. These materials contain lots of useful element for plants (e.g. iron, phosphorus, potassium, zinc). However, their aluminum, chrome and lithium contents are also considerable. The element contents in sewage sludge and the filtrates of lime sludge, as well as the dry matter accumulation and relative chlorophyll contents, were measured. The disadvantageous and advantageous physiological effects of the examined materials were confirmed. The compensation effect of the environment is excluded; however, the neutralization of environmental impacts is not infinite under natural circumstances.

\section{INTRODUCTION}

The main cause of the greenhouse effect is air pollution, including $\mathrm{CO}_{2}$ and other gaseous pollutants, as well as different solid, small-sized and airborne materials. Some of these solid pollution forms are powders that originate from various human activities.

The world's population is growing and it is predicted that it will surpass 8 billion by 2025 . The majority of growth in population is foreseen to take place in developing countries (James, 1997). To feed the world with such a remarkable increase in population, considerable improvement in food production should be achieved in these countries. The current agricultural productivity should be enhanced on cultivated lands, which may tackle this challenge. However, in many developing countries, and particularly in Africa, reduced soil fertility caused by continuous cultivation with low nutrient input and the resultant nutrient exploitation of soils are major threats to both food production and ecosystem viability.

The sustainability of farming and their agro-ecosystems depend on the ability of farmers to overcome current and future threats to the sustenance of their enterprise. These risks can originate from the loss of site productivity e.g. the contaminations can originate from the farms. The not suitable use of pesticides is a danger to our lands and plants. These materials and those of their elements extend with airborne and waterborne flow. Customers do not trust the quality of products, or do not agree with the production conditions.

Plant nutrition research has traditionally focused on the first of these threats and has helped to develop plant and soil management systems that provide for proper nutrient supply to the given crops without inappropriately exploiting soil resources. A build-up of soil nutrients, some of them not being directly available to common crops, has been seen as an unavoidable side-effect of improved crop nutrient.

In addition to the problems of excess nutrition, in extensive parts of the tropical lands the insufficient supply of plant nutrients remains a major constraint on crop growth. The lack of knowledge in relation to plant nutrition is not a major determining factor in this situation. Fertilizers are generally used where people have adequate financial resources for crop production.

Our understanding of plant nutrition is dominated by experiments with and theories on monocultures, and it is possible that options to combine the use of inorganic nutrients with organic sources, alongside with multiple harvestable components, remain underutilized because of the lack of sufficient knowledge.

\section{MATERIALS AND METHODS}

Maize seeds (Zea mays L cvs. Norma SC) were used in the experiments. The seeds were sterilized with $18 \%$ hydrogen peroxide, and then washed in distilled water. The corn seeds were then replaced to $10 \mathrm{mM}$ $\mathrm{CaSO}_{4}$ for 4 hours, but the sunflower seeds were not. After that, they were germinated on moistened filter paper at $25^{\circ} \mathrm{C}$. The seedlings were then transferred to a continuously aerated nutrient solution of the following composition: $2.0 \mathrm{mM} \mathrm{Ca}\left(\mathrm{NO}_{3}\right)_{2}, 0.7 \mathrm{mM} \mathrm{K}_{2} \mathrm{SO}_{4}, 0.5 \mathrm{mM} \mathrm{MgSO}_{4}, 0.1 \mathrm{mM} \mathrm{KH} \mathrm{PO}_{4}, 0.1 \mathrm{mM} \mathrm{KCl}, 1 \mu \mathrm{M} \mathrm{H} \mathrm{BO}_{3}$, $1 \mu \mathrm{M} \mathrm{MnSO}_{4}, 0.25 \mu \mathrm{M} \mathrm{CuSO}_{4}, 0.01 \mu \mathrm{M}\left(\mathrm{NH}_{4}\right)_{6} \mathrm{Mo}_{7} \mathrm{O}_{24}$. Iron was added to the nutrient solution as Fe-EDTA at a concentration of $10^{-4} \mathrm{M}$. The filtrates of the examined industrial wastes were added to the nutrient solution in different quantities. $66 \mathrm{ml} \mathrm{dm}^{-3}$ from the sewage sludge and $100 \mathrm{ml} \mathrm{dm}^{-3}$ from the lime sludge to the nutrient 
solution. The seedlings were grown under controlled environmental conditions (light/dark regime 10/14 h at $24 / 20^{\circ} \mathrm{C}$, relative humidity of $65-70 \%$ and a photosynthetic photon flux of $300 \mu \mathrm{mol} \mathrm{m} \mathrm{m}^{-2}$. The number of repetitions was three. The contents of elements were measured with ICP, the relative chlorophyll contents with of SPAD 502 (Minolta). The samples were dried at $85^{\circ} \mathrm{C}$, the dry matters of shoots and roots were measured. The lime sludge originated from the Ore, Mineral and Waste Recycling Works of Borsod Private Company Limited by Shares (BÉM Zrt.) (Northern Hungary), and the sewage sludge came from Alkaloida Chemicals Co. Ltd. (East Hungary).

\section{RESULTS AND DISCUSSION}

In several respects, the improvement of soil fertility and the efficient use of mineral nutrients is of high ecological and economic importance (Snapp et al. 19989). The use of basic and practical research information provided through plant nutrition studies will play a determinate role in establishing efficient and ecology-based nutrient management systems (Henao and Baanante, 1999). The combination of mineral fertilizers with different types of organic materials, including legumes in rotational cropping systems and recycling crop residues are widely recommended strategies to improve soil fertility and enhance nutrient use efficiency (Higgs et. al., 2000).

The examined matters were supplied in large quantities by the above-named companies. These materials contain lots of useful element for plants (e.g. Fe, K, P. etc.) but the investigated materials contain some heavy metals in addition (Table 1).

Contents of some elements in the raw materils and filtrates of the examined wastes (sewage slugde, lime sludge)(mg kg-1)

\begin{tabular}{|c|c|c|c|c|}
\hline \multirow{2}{*}{ Elements } & \multicolumn{2}{|c|}{ Contents of elements of raw materials $\left(\mathbf{m g ~ k g}^{-1}\right)$} & \multicolumn{2}{c|}{ Contents of elements of filtrates $\left(\mathbf{m g ~ k}^{\mathbf{1}} \mathbf{)}\right.$} \\
\cline { 2 - 5 } & Sewage sludge & Lime sludge & Sewage sludge & Lime sludge \\
\hline \hline $\mathbf{A l}$ & $17,349.00$ & $3,440.00$ & 4.71 & 219.00 \\
\hline $\mathbf{C r}$ & 41.00 & 169.00 & 0.57 & 1.34 \\
\hline $\mathbf{C u}$ & 109.00 & 185.00 & 0.11 & 0.61 \\
\hline $\mathbf{F e}$ & $21,098.00$ & $118,500.00$ & 64.40 & 108.00 \\
\hline $\mathbf{K}$ & $2,878.00$ & $1,010.00$ & 167.00 & 0.19 \\
\hline $\mathbf{L i}$ & 4.21 & 4.70 & 0.04 & 4.91 \\
\hline $\mathbf{M n}$ & 496.00 & $1,983.00$ & 1.15 & 0.16 \\
\hline $\mathbf{N i}$ & 24.50 & 68.00 & 0.13 & 0.16 \\
\hline $\mathbf{P}$ & $21,289.00$ & 162.00 & 6.20 & 2.88 \\
\hline $\mathbf{Z n}$ & 473.00 & 106.00 & 0.69 & \\
\hline
\end{tabular}

The sewage sludge contains some potassium. Potassium is a cation that is present in the largest quantities in plants. Potassium is very important role in the frost tolerance of plants. The uptake of potassium is highly selective, and closely associated with metabolic activities. Potassium is not metabolized, and it forms only weak complexes in which it is readily exchangeable (Wyn Jones et al., 1979). Copper deficiency is often observed in plants growing on soils and low total copper and on soils high in organic matter where copper is a complexed to organic substance (Alloway and Tills, 1984). High nitrogen availability can also aggravate copper deficiency. Plant species differ considerably in sensitivity from copper deficiency with wheat, oat and spinach being much more sensitive than pea, rye or rape. The inhibition of calcium transport to areas of new growth may occur in copper deficient plants (Brown, 1979).

The dry matter accumulation of roots and shoots were higher when sewage sludge was added to the nutrient solution. The dry matter of shoots was under the control in the plants treated with lime sludge but the dry matter of roots was above the control level (Table 2).

Dry matter accumulation of roots and shoots of maize $\left(\mathrm{g} \mathrm{plant}^{-1}\right)$

\begin{tabular}{|c|c|c|}
\hline \multicolumn{3}{|c|}{ Dry matter of roots and shoots $\left(\mathbf{g ~ p l a n t}^{\mathbf{1}}\right)$} \\
\hline Treatments & Roots & Shoots \\
\hline \hline Control & $0.101 \pm 0.05$ & $0.318 \pm 0.11$ \\
\hline Sewage sludge & $0.121 \pm 0.04$ & $0.411 \pm 0.10$ \\
\hline Lime sludge & $0.104 \pm 0.01$ & $0.361 \pm 0.02$ \\
\hline
\end{tabular}


Low chlorophyll content affects photosynthetic activity. The decreasing dry matter accumulation can be explained by the lower level of the chlorophyll contents. The relative chlorophyll contents were shown in the Table 3 .

Relative chlorophyll contents of the $2^{\text {nd }}$ and $3^{\text {rd }}$ leaves of maize (Spad Units) $n=35 \pm$ s.e.

\begin{tabular}{|c|c|c|c|}
\hline \multicolumn{4}{|c|}{ Relative chlorophyll contents of the $2^{\text {nd }}$ leaves } \\
\hline Treatments & $6^{\text {th }}$ days & $9^{\text {th }}$ days & $11^{\text {th }}$ days \\
\hline Control & $38.14 \pm 4.95$ & $48.20 \pm 2.85$ & $49.31 \pm 5.12$ \\
\hline Sewage sludge & $34.07 \pm 7.75$ & $47.27 \pm 4.08$ & $47.92 \pm 4.10$ \\
\hline Lime sludge & $38.10 \pm 4.78$ & $44.05 \pm 2.08$ & $47.40 \pm 2.86$ \\
\hline \multicolumn{4}{|c|}{ Relative chlorophyll contents of the $3^{\text {rd }}$ leaves } \\
\hline Treatments & $6^{\text {th }}$ days & $9^{\text {th }}$ days & $11^{\text {th }}$ days \\
\hline Control & $30.06 \pm 6.06$ & $43.43 \pm 2.49$ & $45.87 \pm 1.98$ \\
\hline Sewage sludge & $32.13 \pm 5.19$ & $41.77 \pm 4.60$ & $46.75 \pm 4.30$ \\
\hline Lime sludge & $33.69 \pm 3.64$ & $42.88 \pm 3.39$ & $47.41 \pm 1.62$ \\
\hline
\end{tabular}

When plants are grown under controlled conditions, cc. $80 \%$ of the iron is localized in the chloroplasts of rapidly growing leaves, regardless of iron nutritional status. Iron can be stored in plant cells in the stroma of plastids as phytoferritin (Seckbach, 1982). Its content is high in dark-grown leaves (up to $50 \%$ of the total iron), but rapidly disappears during re-greening (Mark et al., 1981), and remains very low in green leaves. After resupplying iron to deficient plants, however, the uptake rate is exceptionally high, and the phytoferritin leaf content may transiently increase dramatically (Lobreaux et al., 1992), and makes up as much as 30\% of the total leaf iron (Van der Mark et.al., 1982; Platt- Aloia et al., 1983). The localization of phytoferritin is not confined to chloroplasts: it can also be detected in the xylem and phloem (Smith, 1984). The chlorophyll contents will be larger for larger iron contents (Machold, 1968). The sewage sludge and lime sludge contain a lots of iron (iron content in lime sludge: $241.00 \mathrm{mg} \mathrm{kg}^{-1}$, iron content in sewage sludge: $64.40 \mathrm{mg} \mathrm{kg}^{-1}$ ). The relative chlorophyll contents of the $3^{\text {rd }}$ leaves of corn were higher in plant treated with lime sludge and sewage sludge than the control on the $6^{\text {th }}$ and $11^{\text {th }}$ days of measurement.

\section{CONCLUSION}

The examined matters contain lots of useful elements for plants e.g. potassium, phosphorous, zinc and iron, and some harmful elements e.g. aluminum, chrome and lithium in addition. The plants can uptake these elements, and they may cause different effects on the development and growth of plants. The sewage sludge contains 2.5 times more potassium, 131 times more phosphorous and 4.5 times more zinc than the lime sludge. The sewage sludge contains lots of aluminum. The large quantity of aluminum did cause no harmful deformation on the plants. The dry matter accumulation of roots and shoots were higher when sewage sludge was added to the nutrient solution. The dry matter of shoots was under the control in the plants treated with lime sludge, but the dry matter of roots was above the control level. The relative chlorophyll contents of the $3^{\text {rd }}$ leaves of corn were higher in plant treated with lime sludge and sewage sludge than the control on the $6^{\text {th }}$ and $11^{\text {th }}$ days of measurement.

\section{ACKNOWLEDGEMENT}

I would like to say many thanks to those companies for their help that have made the examined materials available to us: Ore, Mineral and Waste Recycling Works of Borsod Private Company Limited by Shares and Alkaloida Chemicals Co. Ltd.

\section{REFERENCES}

Allway B. J.-Tills A. R. (1984): Copper deficiency in world's crops. Outlook Agriculture 13, pp. 32-42.

Brown J. C. (1979): Role of calcium in micronutrients stresses of plants. Commun. Soil Sci. Plant Anal., 10, pp. 459-472.

Cakmak I.-Kalayci M.-Ekiz H.-Braun H.J.-Kilinc Y.-Yilmaz A. (1999): Zinc deficiency as a practical problem in plant and human nutrition in Turkey: A NATO science for stability project. Field Crops Research 60(1-2): 175-188.

Graham R.D.-Ascher J. S.-Hynes S.C. (1992): Selecting zinc-efficient cereal genotypes 
for soils of low zinc status. Plant Soil 146: 241-250.

Henao J.-Baanante C. (1999): Nutrient depletion in agricultural soils of Africa. 2020 Vision Brief 62. Washington, D.C. IFPRI.

Higgs B.-Johnston A.E.-Salter J.L.-Dawson C. J. (2000): Some aspects of achieving sustainable phosphorus use in agriculture. J. Environmental Quality, 29, pp. 80-87.

James C. (1997): Progressing Public-Private Sector Partnerships in International Agricultural Research and Development. ISAAA No. 4. pp $2-26$

Sanchez P. A.-Salinas G. (1981): Low input technology for managing Oxisols and Ultisols in tropical America. Adv. Argon 34, pp. $280-406$. Snapp S.S.-Mafongoya P. L.-Waddington S. (1998): Organic matter strategies for integrated nutrient management in smallholder cropping systems of southern Africa. Agric. Ecosystem. Environ. 71, pp. 158-200.

Takkar P. N.-Chibba I. M.-Mehta S. K. (1989): "Twenty years of Co-ordinated research of micronutrients in soil and plants (1967-1987)". Indian Institute of Soil Science. Bhopal IISS. Bull.

Wyn Jones R. G.-Bradly C. J.-Speirs J. (1979): Ionic and osmotic relations in plant cells. In Recent Advances in the Biochemistry of Cereals (D.L. Laidman and R.G. Wyn Jones, eds.), pp.63-103. Academic Press, London. 